\title{
Penggunaan Tutor Sebaya untuk Meningkatkan Hasil Belajar Fisika Kelas X B di SMA Negeri 1 Gumbasa
}

\section{Safrudin, Kamaluddin dan Haeruddin}

E-mail: safrudinfisika@yahoo.co.id

Program Studi Pendidikan Fisika, Jurusan Pendidikan MIPA, Universitas Tadulako

Jl. Soekarno Hatta KM.9 Kampus Bumi Tadulako Tondo Palu - Sulawesi Tengah

\begin{abstract}
Abstrak - Penelitian ini adalah penelitian tindakan kelas dengan menerapkan tutor sebaya untuk meningkatkan hasil belajar. Penggunaan tutor sebaya adalah pembelajaraan yang memanfaatkan teman sekelas yang mempunyai kemampuan lebih untuk membantu temannya dalam melaksanakan suatu kegiatan atau memahami konsep pembelajaran. Masalah yang hendak dipecahkan dalam penelitian ini adalah rendahnya hasil belajar fisika siswa kelas XB di SMA Negeri 1 Gumbasa, penelitian ini terdiri dari dua siklus, pada setiap siklus terdiri dari empat tahap yaitu; Perencanaan, Pelaksanaan, Observasi, dan Refleksi. Penelitian ini melibatkan 25 orang siswa kelas XB SMA Negeri 1 Gumbasa yang terdiri dari 17 siswa perempuan dan 8 siswa laki-laki. Hasil penelitian menunjukan bahwa terjadi peningkatan hasil belajar siswa seiring dengan diterapkannya tutor sebaya. Hasil observasi aktivitas siswa yang diperoleh pada siklus I yakni 50,00\% dan 62,50\% atau dalam kategori cukup, pada siklus II diperoleh aktivitas siswa $87,50 \%$ dan $93,75 \%$ dengan peningkatan aktivitas siswa berada dalam kategori baik dan sangat baik. Hasil belajar pada siklus I dan siklus II yaitu skor rata-rata pada siklus I adalah 52,56 dan skor rata-rata pada siklus II yaitu 70,12. Dengan demikian, berdasarkan hasil penelitian menunjukan bahwa penggunaan tutor sebaya dapat meningkatkan hasil belajar dan aktivitas siswa kelas XB SMA Negeri 1 Gumbasa.
\end{abstract}

\section{Kata Kunci: Penerapan Tutor Sebaya, Hasil Belajar Fisika}

\section{PENDAHULUAN}

Salah satu indikasi peningkatan kualitas pendidikan dapat dilihat dari adanya peningkatan potensi akademik atau hasil belajar siswa secara keseluruhan yang meliputi tiga aspek, yaitu : kognitif, afektif, dan psikomotor. Dalam rangka meningkatkan hasil belajar siswa dan tercapainya pendidikan nasional, ketiga aspek tersebut harus diperhatikan sehingga proses belajar mengajar tidak hanya menekankan pada pemahaman siswa tetapai juga menerapkan atau mengaplikasikan dalam kehidupan sehari-hari.

Hasil belajar di SMA Negeri 1 Gumbasa masih tergolong rendah dan nampak keindividual siswa antara siswa yang memiliki kemampuan rendah dan siswa yang memiliki kemampuan tinggi akibatnya cendrung siswa yang pintar yang lebih aktif dan mendapatkan hasil belajar yang baik sedangkan siswa yang kurang pintar mendapatkan nilai yang kurang baik, hasil belajar siswa yang bervariasi ini menimbulkan kurang kerja sama siswa antara siswa yang pintar dan siswa yang kurang pintar, sehingga guru bidang studi diharapkan bisa menyelesaikan masalah tersebut dengan menggunakan beberapa metode ajar yang lebih menarik.

Data yang diperoleh dari SMA Negeri 1 Gumabasa di Kelas X B menunjukan bahwa siswa yang mengikuti mata pelajaran Fisika tahun ajaran 2012/2013 semester genap 


\section{Jurnal Pendidikan Fisika Tadulako (JPFT) \\ Vol. 1 No. 3}

ISSN 23383240

berjumlah 25 siswa, dengan siswa yang memperoleh nilai dibawah standar ketuntasan minimal (65) berjumlah 18 orang dan siswa yang memperoleh nilai diatas standar ketuntasan minimal berjumlah 7 orang dengan hasil ini menunjukan tingkat individual siswa antara siswa pintar dan siswa yang kurang pintar, Guru bidang studi tidak mungkin akan menangani satu persatu siswa yang mengalami kesulitan belajar sehingga diharapkan siswa yang pintar dapat membantu siswa yang menagalami kesulitan belajar dan siswa yang mengalami kesulitan belajar mau bertanya dengan siswa yang pintar, jika hal ini dibiarkan akan menimbulkan dampak yang negatif, yang lebih besar terhadap hasil belajar siswa dan menimbulkan kesan bahwa mata pelajaran fisika sangat sulit untuk dipelajari dan dipahami. Berdasarkan uraian diatas diperlukan suatu metode ajar alternatif yaitu metode pembelajaraan Cooperative learning (pembelajaran kooperatif) yaitu pembelajaran yang mengacu pada tiga tujuan intraksional yakni hasil belajar akademik, penerimaan terhadap keragaman dan pengembangan keterampilan sosial [2].

Bantuan tutor adalah seorang yang dapat membantu murid secara individual artinya siswa yang mengalami kesulitan belajar diberi bantuan oleh teman-teman mereka sekelas yang punya umur sebaya. Tutor sebaya adalah seorang teman atau beberapa orang siswa yang ditunjuk oleh guru (sesuai keriteria menjadi tutor sebaya) dan ditugaskan untuk membantu siswa yang mengalami kesulitan. Pengajaran dengan tutor sebaya adalah kegiatan belajar siswa dengan memanfaatkan teman sekelas yang mempunyai kemampuan lebih untuk membantu temannya dalam melaksanakan suatu kegiatan atau memahami konsep [1].

\section{METODOLOGI PENELITIAN}

Penelitian ini adalah penelitian tindakan kelas. Pelaksanan penelitian ini meliputi beberapa tahap yang tiap tahapnya disebut siklus. Penelitian ini dilaksanakan 2 siklus, masing masing siklus terdiri dari beberapa tahap, yaitu refleksi awal, perencanaan, pelaksanaan tindakan, observasi, evaluasi, dan refleksi. Adapun tahap pelaksanaan penelitian tindakan kelas ini mengacu pada desain yang dikemukakan oleh Kemmis dan Mc. Taggart [3].

Subjek penelitian adalah siswa kelas X B yang mengikuti mata pelajaran IPA Fisika tahun ajaran 2012/2013, dengan jumlah siswa 25 orang yang terdiri dari 8 orang siswa laki - laki dan 17 orang siswa perempuan. Data yang dikumpulkan dalam penelitian ini adalah hasil belajar siswa dalam mengerjakan soal-soal fisika yang diberikan melalui tes akhir setiap tindakan dan hasil observasi yang memuat catatan 


\section{Jurnal Pendidikan Fisika Tadulako (JPFT) \\ Vol. 1 No. 3}

ISSN 23383240

mengenai kegatan pembelajaran, baik yang berkaitan dengan guru (peneliti) maupun yang berkaitan dengan siswa, serta hasil belajar siswa.

\section{HASIL DAN PEMBAHASAN}

Pada pembelajaran siklus I dilakukan dengan membagi siswa dalam 5 kelompok, setiap kelompok terdiri dari 5orang dengan satu tutor. Siswa dibagikan LKS untuk dikerjakan secara berkelompok, mendiskusikan dan mempresentasekan di depan kelas.

Pelaksanaan tindakan pada siklus I yang hendak dilaksanakan mengacu pada perencanaan tindakan siklus I yang terdiri dari skenario pembelajaran yang telah disusun kemudian penyajian materi yang dilaksanakan sebanyak 2 kali pertemuan, setiap kali pertemuan atau tatap muka dilakukan pengisian lembar observasi siswa, guru dan evaluasi proses siswa pada saat KBM berlangsung oleh observer. Kemudian pada akhir pelaksanaan siklus dilakukan evaluasi terhadap siswa guna mengetahui hasil belajar atau kemampuan siswa.

Berdasarkan hasil observasi guru pada siklus I jumlah skor yang diperoleh pada pertemuan pertama adalah 17 dari skor maksimal 28 dengan demikian persentase ketercapaian adalah 67,71\%. Observasi guru pada pertemuan kedua jumlah skor yang diperoleh adalah 20 dengan skor maksimal 28 dengan demikian persentase ketercapaian adalah $71,42 \%$. merujuk pada pedoman penilaian kualitatif yaitu cukup pada pertemuan 1 pada pertemuan 2 berada dalam kategori baik.

Hasil observasi guru pada siklus II dengan jumlah skor yang diperoleh pada pertemuan pertama adalah 23 dari skor maksimal 28, dengan demikian persentase nilai rata-rata adalah $82,14 \%$ dengan kategori baik. Observasi guru pada pertemuan kedua jumlah skor yang diperoleh adalah 26 dengan skor maksimal 28 dengan demikian persentase nilai rata-rata 92,85\%, merujuk pada pedoman penilaian kualitatif adalah Baik pada pertemuan pertama maupun kedua yang berada dalam kategori sangat baik.

Hasil Observasi siswa pada siklus I memperlihatkan bahwa pada pertemuan 1 persentase skor untuk aktivitas siswa 50,00\%, persentase tersebut sudah masuk dalam kategori cukup, sedangkan untuk pertemuan 2 persentase skornya sudah mengalami peningkatan dari pertemuan pertama menjadi $62,50 \%$ tetapai masih dalam kategori cukup, sehingga dari keseluruhan jenis penilaian aktivitas siswa yang diamati dalam kegiatan belajar mengajar (KBM), rata-rata berada dalam kategori cukup, tetapi terdapat beberapa aspek indikator aktivitas siswa sudah berada dalam kategori baik

Hasil observasi aktivitas siswa pada siklus II memperlihatkan bahwa pada pertemuan 1 persentase skor untuk aktivitas siswa adalah $87,50 \%$, keriteria keberhasilannya adalah baik, sedangkan untuk pertemuan kedua persentase skornya adalah 93,75\% dengan keriteria keberhasilannya menunjukan sangat baik. Sehingga dari seluruh jenis aktivitas siswa yang diamati dalam kegiatan belajar mengajar (KBM), rata-rata berada dalam kategori sangat baik.

Hasil observasi aktivitas siswa yang plaing meningkat adalah siswa aktifdalam kerja kelompok. Hal ini disebabkan karena siswa tidak merasa malu atau segan lagi bertanya tentang 


\section{Jurnal Pendidikan Fisika Tadulako (JPFT) \\ Vol. 1 No. 3}

ISSN 23383240

materi yang belum dipahami karena bimbingan tutor sebaya, siswa terbiasa hadir pada tepat waktu, perhatian dalam mengikuti pelajaran, mampu bersosialisai dengan teman-temannya.

Hasil tes tindakan siklus I diperoleh bahwa ada sebagian siswa belum mampu mengerjakan soal yang diberikan terutama nomor 8 dan 9, penyebabnya adalah siswa kurang mampu dalam menghitung dan tidak memahami konsep kelistrikan dengan baik, siswa tidak termotivasi untuk belajar, tidak menyalin kembali penjelasan materi yang disampaikan oleh guru dengan serius. Tetapi pada siklus II hasil belajar siswa sudah memenuhi indikator kinerja yang telah ditetapkan.

Tabel 1. Hasil analisis skor perolehan siswa pada siklus I dan siklus II

\begin{tabular}{|l|l|l|l|}
\hline & & Siklus I & Siklus II \\
\hline DSK & & $57,17 \%$ & $87,65 \%$ \\
\hline
\end{tabular}

Hasil analisis pada siklus I diperoleh bahwa daya serap klasikal belum memenuhi indikator kinerja yang ditetapkan sebesar $80 \%$, sehingga masih ada sejumlah tujuan pembelajaran yang belum tercapai

Hasil analisis tes tindakan siklus II seperti yang terlihat pada tabel diatas telah mencapai indikator keberhasilan siswa 87,65\%. Oleh karena itu pokok bahasan listrik dinamis dianggap tuntas dan selesai.

Penelitian ini bertumpu pada tutor sebaya dimana siswa belajar dengan bimbingan tutor dalam penyelesaian LKS sehingga siswa mendapat pengalaman dalam menemukan konsep kelistrikan dibawah bimbingan tutor sebaya, dengan menggunakan bimbingan tutor sebaya siswa tidak malu dalam bertanya tentang materi yang tidak dimengerti dan diharapkan siswa dapat memahami konsep-konsep kelistrikan serta hasil belajar siswa dapat meningkat.

Pada siklus I hasil yang diperoleh berdasarkan daya serap klasikal (DSK) yaitu sebesar $57,17 \%$ sehingga pada siklus I belum memenuhi indikator kinerja yang ditentukan dalam indikator kinerja sebesar $80 \%$, tetapi aktivitas siswa yang diperoleh sebesar $62,50 \%$ dalam kategori Cukup dan penilaian afektif yang diperoleh sebesar $76,00 \%$ dalam kategori Cukup. Pada aktivitas siswa terdapat aspek yang persentasenya masih dalam kategori cukup dari yang lain yaitu siswa kurang menyimak penjelasan materi yang disampaikan oleh guru, kurang aktif dalam diskusi kelompok, dan kurang menghargai tutor yang telah ditunjuk untuk membimbing, serta siswa kurang mampu menyimpulkan materi yang diajarkan. Untuk penilaian afektif siswa terdapat aspek yang persentasenya masih dalam kategori cukup dari aspek yang lain yaitu kurang menghargai tutor dan disiplin masuk kelas, serta mengerjakan LKS masih kurang baik, hal ini disebabkan sebagian siswa masih ada yang bermain-main sehingga tidak konsentrasi dalam pembelajarannya. Sehingga pada siklus I masih ada sejumlah tujuan pembelajaran yang belum tercapai seperti pada soal nomor 8 tentang hambatan listrik dalam penghantar. Dengan demikian permasalahan tersebut, menyebabkan siswa tidak memahamai bagaimana cara menyelesaikan soal perhitungan kuat arus listrik dan tidak memahami konsep kelistrikan, siswa tidak sering membaca kembali materib yang telah diajarkan sampai dirumah, siswa kurang mampu mengembangkan idenya untuk soal yang membutuhkan imajinasi dan siswa kurang 


\section{Jurnal Pendidikan Fisika Tadulako (JPFT) \\ Vol. 1 No. 3}

ISSN 23383240

diberi kesempatan bertanya saat kegiatan belajar mengajar. Dalam hal ini, aktivitas siswa dan penilaian afektif siswa dalam melakukan kegiatan belajar mengajar di kelas.

Dengan penerapan tutor sebaya hasil belajar siswa meningkat ditandai dengan hasil belajar yang menujukan peningkatan dan aktivitas siswa yang jauh lebih baik. Pada siklus II guru mengusahakan meminimalisir keurangan-kekurangan pada siklus I, sehingga hasil pada siklus II meningkat dari pada siklus I. Hal ini terlihat dari hasil skor rata-rata siswa meningkat dari $52,56 \%$ menjadi $70,12 \%$.

Hasil penelitian diatas tampak bahwa dengan menerapkan tutor sebaya telah mencapai ketuntasan belajar melebihi standar yang ditetapkan yaitu $80 \%$. Dari data hasil observasi terhadap kegiatan pembelajaran sikkus I dan siklus II tampak bahwa aktivitas siswa dan guru selama mengikuti pembelajaran sudah memenuhi indikator kinerja.

Hasil ini terlihat bahwa nilai-nilai rata-rata dari siklus I dan siklus II meningkat yaitu $52,56 \%$ menjadi 70,12\%. Berdasarkan hasil tersebut menunjukan bahwa hasil belajar fisika siswa pada materi listrik dinamis mengalami peningkatan. Dengan penerapan tutor sebaya, siswa lebih aktif bertanya dengan tutor karena tidak malu atau segan, termotivasi untuk belajar bekerja sama dalam kelompok untuk menyelesaikan masalah, melakukan diskusi bersma tutor untuk mendapatkan informasi konsep kelistrikan yang lebih mendalam.

$$
\begin{aligned}
& \text { IV. KESIMPULAN } \\
& \text { Berdasarkan hasil penelitian dan }
\end{aligned}
$$
pembahasan dapat disimpulkan bahwa dengan penggunaan tutor sebaya dalam pembelajaran fisika dapat meningkatkan hasil belajar siswa kelas XB SMA Negeri 1 Gumabasa, selain itu aktivitas siswa masuk dalam kategori baik dalam merespon pembelajaran fisika yang menggunakan tutor sebaya.

Masalah yang dihadapi dalam penerapan tutor sebaya yaitu dalam mempersiapkan tutor memerlukan bayak waktu dan memberi prifate pada siswa yang menjadi tutor yang diberikan diluar jam sekolah.

\section{DAFTAR PUSTAKA}

[1] S.Nasution. 2003.berbagai pendekatan dalam proses belajar mengajar. Cetakan VIII.Jakarta : Bumi Aksara

[2] Mustanin, Nur.2000.pengajaran berpusat pada siswa dan pendekatan kontruktivis dalam pengajaran.surabaya: University Press.

[3] Depdiknas.2003. penelitian tindakan kelas. Bahan ajar pembekalan Guru bantu. 